\title{
DEVELOPING EXPLICIT MEASURES OF STEREOTYPES AND ANTI-ROMA PREJUDICE IN SLOVAKIA: CONCEPTUAL AND METHODOLOGICAL CHALLENGES ${ }^{1}$
}

\author{
BARBARA LÁŠTICOVÁ AND ANDREJ FINDOR
}

\begin{abstract}
The paper discusses the conceptual and methodological challenges of developing measures of stereotypes and prejudice for use in Slovakia. Developing these measures was the first step in a research project aimed at testing the effectiveness of direct and indirect contact interventions to reduce prejudice against stigmatized minorities, particularly the Roma. The first major problem in this kind of research relates to measuring the impact of interventions, as standardized instruments for measuring prejudice have yet to be developed in Slovak. The second problem concerns the risk that the interventions will fail to reduce anti-Roma prejudice, because of the strong stigmatization of the Roma minority in Slovakia. The paper also reviews existing measures of stereotypes and prejudice in social psychology and discusses their applicability for measuring anti-Roma prejudice in Slovakia. It is argued that measures of stereotypes and prejudice should be designed and used in a sensitive manner and that in the process of measuring various forms of social bias we should avoid reproducing its cognitive, emotional and behavioural manifestations.
\end{abstract}

Key words: stereotypes; prejudice; explicit measures; Roma; Slovakia.

\section{Introduction}

In this paper we reflect on and discuss the conceptual and methodological challenges we have faced when adapting and developing explicit measures of stereotypes and prejudice. Developing these measures was the first step in INTERMIN ${ }^{2}$, an ongoing research project to

\footnotetext{
${ }^{1}$ This work was supported by the Slovak Research and Development Agency under contract no. APVV14-0531.

${ }^{2}$ INTERMIN is the abbreviated title of the following project "Interventions for Reducing Prejudice against Stigmatized Minorities: Developing measures and experimental testing of the contact hypothesis under field conditions.” The members of the research team are Barbara Lášticová (principal investigator), Magda Petrjánošová, Simona Andraščiková (all from the Institute for Research in Social Communication, Slovak Academy of Sciences), Andrej Findor, Martin Kanovský, Miroslav Popper, Peter Drál' (all from the Faculty of Social and Economic Sciences, Comenius University in Bratislava), and Miroslav Sirota from the University of Essex, UK.
} 
experimentally test the effectiveness of direct and indirect contact interventions in reducing anti-Roma prejudice in Slovakia. If proven to be effective, these interventions could be implemented in lessons attended by the target population of high school students. We do not present data-based research findings in this paper but strive nonetheless to provide an insight into the process of conducting research with all its inherent difficulties and successes.

The project main objectives are as follows: 1 . To experimentally test, in randomized controlled trials, the effect of three types of interventions (based on direct, vicarious and imagined contact) on reducing explicit and implicit prejudice against members of the Roma minority. 2. To test the effect of the interventions on discriminatory behaviour.

The first major problem in such a research endeavour is that the standardized instruments for measuring direct and indirect prejudice that would enable us to test the effectiveness of the interventions (and make international comparisons) have yet to be developed in Slovak. So our first task was to adapt existing research instruments. The second problem concerns the risk that the interventions will fail to reduce anti-Roma prejudice in Slovak schools since the Roma in Slovakia face enormous prejudice, discrimination and social exclusion in different areas of social life. This paper predominantly focuses on the first problem-measuring anti-Roma prejudice and the effectiveness of interventions-but also briefly addresses the challenges that arise when attempting to reduce anti-Roma prejudice in Slovakia, since these two problems are interrelated.

In the article that follows we first briefly describe the situation of the Roma in Slovakia. Second, we explain how we conceptualize prejudice in our project and how that has been informed by consideration of the conceptualization problems that have been identified in social psychology research. Third, we present our visions of how to reduce prejudice against Roma in Slovak schools, focusing on the rationale behind the INTERMIN project. Fourth, we discuss the existing explicit ${ }^{3}$ attitudinal emotional and behavioural measures in the social psychology literature, and how they relate to existing measures of anti-Roma prejudice in Slovak and Czech social psychology. ${ }^{4}$ Fifth, we review the measures used in our project. Finally, we discuss the main problems that arose when adapting these measures for Slovak language and culture.

\footnotetext{
${ }^{3}$ Although we will also use implicit measures of prejudice and stereotypes such as IAT in the project, in this paper we focus on the explicit measures, since we already have adapted and validated them in Slovakia and can therefore discuss the problems that arose during development. The Implicit Association Test (IAT) is the most widely used test of uncontrolled and automatic prejudice, which is designed to avoid the interference of impression management common in explicit self-report measures. IAT measures the speed and accuracy of reaction to two sets of different categorization stimuli (Greenwald, McGhee, \& Schwartz, 1998). Despite extensive debate about its validity, IAT has become an established tool for measuring implicit prejudice in addition to self-report measures (Banaji \& Greenwald, 2013).

${ }^{4}$ In this paper, we repeatedly refer to the research conducted in the Czech Republic because of its linguistic and cultural proximity to Slovakia and to the similar patterns and dynamics found in intergroup relations with the ethnic majority (Czechs or Slovaks) and the minority (Roma) in the two countries, which were formerly part of the common state of Czechoslovakia (1918-1992, excluding a brief period during WWII).
} 


\section{Roma in Slovakia: a large yet stigmatized minority}

According to the last census (Štatistický úrad SR, 2011), 105,738 Slovak citizens ${ }^{5}$ declared their ethnicity to be Roma, making Roma the third biggest ethnic group in Slovakia, right after the Slovak and Hungarian ethnic groups. However, the number of Roma is higher than the official statistical data suggests, as many Roma do not self-declare as Roma in the census, but claim Slovak or Hungarian ethnicity instead. One explanation for this phenomenon is the low ethnic pride of Roma, resulting from their stigmatization and discrimination (Vašečka, 2002). The authors of the comprehensive Atlas of Roma communities in Slovakia (ATLAS rómskych komunit na Slovensku 2013) estimate the number of Roma in Slovakia to be four times higher than the census data (approx. 402 840). The majority of Roma live in eastern Slovakia (the Košice and Prešov regions) and in south-eastern districts found in the Banská Bystrica region (Mušinka, Škobla, Hurrle, Matlovičová, \& Kling, 2014).

Since the 1990s, sociological surveys have repeatedly shown a high degree of social distance between the ethnic majority and the Roma minority, equally distributed across all strata of the population (Vašečka, 2002). It is higher than the social distance found in relation to other stigmatized minorities, such as gays and lesbians, alcoholics or drug addicts (Vašečka, 2001). The stigmatization of the Roma minority in Slovakia was also reported in the 2015 Special Eurobarometer survey, in which only 17\% of respondents from Slovakia declared that they would feel comfortable if their child was in a romantic relationship with a Rom (the EU country average was 53\%) (European Commission, 2015). Only in Bulgaria (13\%) and the Czech Republic (11\%) were the percentages lower.

Slovak Roma are discriminated against in healthcare and education, on the labour market, and by public institutions (Popper, Szeghy, \& Šarkozy, 2009; Popper, Szeghy, Poduška, \& Kollárik, 2011; Machlica, Žúdel, \& Hidas, 2014). Their marginalized position is exacerbated by the spatial segregation of many Roma settlements (Rusnáková \& Rochovská, 2014). Moreover, the recent parliamentary elections in March 2016 saw the rise of a right-wing extremist political party Kotleba - Ludová strana Naše Slovensko (Kotleba - Our Slovakia People's Party), which campaigned on an explicitly anti-Roma agenda. Repeatedly referring to the Roma as "parasites", the campaign voiced the dehumanizing tendencies inherent in the harsh public treatment and depiction of the Roma in Slovakia. ${ }^{6}$

\section{Conceptualizing prejudice in contemporary social psychology: problems and challenges}

The classic and still widely used definition of prejudice is one formulated by psychologist Gordon Allport: "Prejudice is an antipathy based on faulty and inflexible generalization. It may be felt or expressed. It may be directed toward a group or an individual of that group" (Allport, 1979, p. 9). Since Allport's seminal book The Nature of Prejudice, first published

\footnotetext{
${ }^{5}$ According to the last census (2011) the total population of Slovakia is 5,397,036.

${ }^{6}$ No research has been published in Slovakia that would explore this issue; however, a study conducted in Hungary provides valuable insight into the blatant and subtle dehumanization of Roma and the findings can be applied to the situation in Slovakia as well (Kteily, Bruneau, Waytz, \& Cotterill, 2015).
} 
in 1954, the concept of prejudice has become a fundamental component in assessing the social psychology of intergroup relations and has led to different explanations for prejudice (Dixon \& Levine, 2012b). The first research to be conducted, inspired by the post-war concept of the Authoritarian Personality (Adorno, Frenkel-Brunswik, Levinson, \& Sanford, 1950), explained prejudice as the result of abnormal personality development. Later on, social cognition researchers conceptualized prejudice as the result of normal yet imperfect information processing (Fiske \& Taylor, 1984). Finally, unconscious, automatic (Greenwald \& Banaji, 1995), and aversive processes (Dovidio \& Gaertner, 2004) came to the fore in prejudice research. Conceptual distinctions have also been made and scales developed to measure old fashioned and "new" symbolic prejudice (Kinder \& Sears, 1981); implicit and explicit prejudice ${ }^{7}$ (Greenwald \& Banaji, 1995); subtle and blatant prejudice (Pettigrew \& Meertens, 1995); and traditional and modern racism (McConahay, 1986). The discursive and societal underpinnings of racism and prejudice have inspired an integral paradigm of research in social psychology (Wetherell \& Potter, 1992; Durrheim, Mtose, \& Brown, 2011, etc.). Recently, there have been arguments in favour of re-considering the person and personalitybased explanations of prejudice, but only in relation to situation-based explanations (Hodson \& Dhont, 2015).

Using the multicomponent "ABC" model of attitudes (Zanna \& Rempel, 1988), prejudice can be conceptualized as the combination of negative affect-emotions (A), derogatory cognitive beliefs—stereotypes (C) and hostile behaviour-discrimination (B) (Brown, 2011, cited in Birtel \& Crisp, 2015). Prejudice does not concern only social groups such as ethnic minorities but is an inseparable component of social stigmatization often aimed against other groups, such as sexual minorities and people suffering from mental illness (Birtel \& Crisp, 2015). ${ }^{8}$ Prejudice can lead to contact avoidance and negative behaviour towards the stigmatized group (Stephan \& Stephan, 1985). Negative or no prior outgroup experiences have consequences for all three components of the ABC of prejudice (Birtel \& Crisp, 2015).

Recently, a number of books have been published that critically assess the current research on prejudice and stereotypes in social psychology and offer alternative conceptualizations, research methodologies and intervention strategies. The most relevant of these to our research are the edited volumes Beyond Prejudice (Dixon \& Levine, 2012a) and Moving beyond Prejudice Reduction (Tropp \& Mallett, 2011a). The main criticisms made by the authors that contributed to these volumes in relation to the current prejudice and stereotypes research concern:

- Theoretical and methodological individualism: a focus on cognitions, emotions, personality and conducting experiments on individuals in the lab, despite the fact that

\footnotetext{
${ }^{7}$ According to Correll, Judd, Park, \& Wittenbrink (2010), the distinction between explicit and implicit measures is not identical to the distinction between controlled and automatic processes. Although implicit measures may yield insights into automatic processes and explicit measures largely tap controlled processes, Correll et al. (2010) consider a measure to be either implicit or explicit and cognitive processes to be either automatic or controlled.

${ }^{8}$ In a recent large-scale survey carried out among Slovak primary and secondary schools students, the groups least acceptable to the students were the mentally ill and sexual minorities (Štátna školská inšpekcia, 2016a,b).
} 
prejudice is a collaborative and social relationship-driven endeavour (Dixon \& Levine, 2012b; Condor \& Figgou, 2012; Durrheim, 2012, etc.);

- The focus on irrationality and biased information processing: exploring prejudiced personality, psychodynamic explanations of prejudice, misperception of social reality (Dixon \& Levine, 2012b; Reicher, 2012, etc.);

- Concentrating on negative attitudes and emotions although outgroup attitudes often have mixed valence (Dixon \& Levine, 2012b; Reicher, 2012; Tropp \& Mallett, 2011b; Gartner \& Dovidio, 2011), the main criticism being that positive and negative attitudes differ in their ability to predict positive and negative behaviours (Pittinsky, Rosenthal, \& Montoya, 2011);

- Prejudice reduction interventions are designed for historically advantaged social groups, following the logic that prejudice reduction in majority members will solve the intergroup conflict, a logic that shifts the power to make social change happen even further away from the stigmatized minorities (Dixon et al., 2015).

At the same time, however, Dixon and Levine (2012b) raised the question of what kinds of methodological and analytic frameworks might allow researchers to best clarify the complex interrelations between "societal" and "personal" factors in order to overcome theoretical and methodological individualism. Despite the criticism mentioned above, they recognize that "conceptual frameworks and methodological practices that inform psychological research on prejudice continue to perpetuate an individualistic perspective on intergroup relations" (p. 7). In our research we draw on the broad conceptualization of prejudice that is in line with the definition proposed by Allport while trying to take a reflexive stance on the shortcomings pointed out by traditional prejudice research critics. In what follows we explain how we plan to overcome some of these.

First, our aim is to reduce methodological individualism by conducting the interventions and measuring their effects outside the lab, in schools, where the pupils will be collectively engaged in direct and indirect contact interventions - building on their relations with one another and not individually (Paluck, Shepherd, \& Aronow, 2016). We also aim to measure the potential behaviour change that occurs in the real life social context of the participants. Nonetheless, the "effects" of the interventions on the ABC of prejudice will be measured again at the individual participant level.

Second, we focus on a mix of positive and negative attitudes, emotions and behavioural intentions. Although Pittinsky et al. (2011) advocate a deeper understanding of positive outgroup attitudes as these are particularly likely to trigger proactive and prosocial behaviours (p. 42), we are unable to use solely positively framed measures, such as their "Allophilia scale", developed to measure positive attitudes toward out-groups. This scale presupposes a quality of contact between members of the non-Roma majority and the Roma minority that sadly does not exist in Slovakia due to the stigmatization of Roma in Slovak society.

However, our approach to prejudice reduction is not capable of overcoming another shortcoming in the traditional prejudice research: the focus on historically advantaged majority groups (Dixon, Durrheim, Thomae, Tredoux, Kerr, \& Quayle, 2015).

In fact, prejudice against Roma is largely socially shared and is not normatively condemned in Slovak society, since it is publicly endorsed by the general public and by 
politicians (see Plichtová \& Paholíková, 2014). The recent electoral success of the Slovak extreme right party Kotleba - Ludová strana Naše Slovensko (with an explicitly anti-Roma racist agenda) in the parliamentary elections of March $2016^{9}$ has largely been attributed to first time voters freshly out of high school and therefore justifies our focus on ethnic majority high school students (14-18 years old). The need to examine the different factors underlying the prejudice in Slovak schools, and look at various prejudice reduction strategies, has also been recognized by the State School Inspectorate (SSI). ${ }^{10}$ At present no data is systematically collected on Slovak students' knowledge of human rights issues, citizenship and historical memory that could be used in connection with perceptions of intergroup relations. The SSI recently launched a project to investigate the relationship between history and civic education knowledge and students' attitudes towards members of minorities and extremist views. ${ }^{11}$

Finally, we are well aware that social psychology researchers have begun to shift away from a common focus on prejudice reduction to consider novel approaches to understanding and promoting positive intergroup relations. Working in diverse yet segregated European, American and South African societies and in contexts where groups have long been in conflict, they are attempting to ascertain how positive feelings of inclusion and acceptance can be fostered to promote forgiveness and mutual understanding between majority and minority groups (Tropp \& Mallet, 2011b). However, as the traditional prejudice reduction approach that uses direct and indirect contact interventions has not yet been experimentally tested in Slovakia, we have opted to start with this approach. We believe that the main challenge will be verifying whether interventions that have succeeded in other cultures and with outgroups other than Roma will also succeed in Slovakia.

\section{Can we reduce anti-Roma prejudice using intergroup contact in Slovakia?}

Despite the previously mentioned shortcomings of the intergroup contact approach to reducing prejudice (Allport, 1979), we recognize that the effectiveness of various types of intergroup contact interventions has been widely documented in the literature. Direct interpersonal contact has repeatedly proven to be an efficient tool for reducing intergroup prejudice (Pettigrew \& Tropp, 2006). Later studies showed that different forms of indirect contact also have a prejudice reducing effect. The extended contact hypothesis (Wright, Aron, McLaughlin-Volpe, \& Ropp, 1997) posits that merely by learning that a member of his/her ingroup is in close contact with an outgroup member, an individual can improve his/her attitudes towards the outgroup. Where vicarious contact is concerned, the positive effect is generally conveyed by characters from literature, in the best cases by those that have

\footnotetext{
${ }^{9}$ These elections saw an extremist right-wing political party enter Slovak parliament for the first time.

${ }^{10}$ The SSI is a state agency tasked with supervising teaching quality, conditions in schools and management and training (https://www.ssiba.sk/Default.aspx?text=g\&id=33\&lang=en).

${ }^{11} \mathrm{http} / / /$ domov.sme.sk/c/20171299/inspekcia-chce-zistit-ako-suvisia-poznatky-ziakov-s-ich-hodnotami. html? ref=trz\%3Ft\%3DIn\%C5\%Alpekcia+chce+zisti\%C5\%A5\%2C+ako+s\%C3\%BAvisia+poznatky+ $\% \mathrm{C} 5 \%$ BEiakov+s+ich+hodnotami. This project, carried out with some of our research team members, attempts to bridge the gap between the academic and pedagogical approaches to reducing prejudice addressed in detail by Drál and Findor (2016, this issue).
} 
saturated that particular cultural environment and can easily be accessed during lessons, such as the Harry Potter book series (Vezzali, Stathi, \& Giovannini, 2012; Gierzynski \& Eddy, 2013; Vezzali, Stathi, Giovannini, Capozza, \& Trifiletti, 2015). Imagined intergroup contact (Turner, Crisp, \& Lambert, 2007) is based on the mental simulation of social interaction between ingroup and outgroup members and significantly reduces intergroup bias in four key areas: intergroup attitudes, emotions, behavioural intentions and behaviour, and its effect is equally strong with explicit as with implicit measures (Miles \& Crisp, 2014). Therefore, the plan is for the INTERMIN project to compare the effects of direct, vicarious and imagined contact interventions in field experiments with high school students using both explicit (selfreport) and implicit measures of prejudice as well as measures of discriminatory behaviour.

However, we have some reservations about the feasibility of intergroup contact interventions in Slovakia, especially in relation to whether they can reduce anti-Roma prejudice. As mentioned, anti-Roma prejudice is deeply embedded in Slovakia and there are great differences in status between the Roma minority and non-Roma ethnic majority, which reproduce strong intergroup boundaries. Although indirect contact interventions have been effective in high-prejudice societal contexts (e.g. West, Husnu, \& Lipps, 2015), designing an intervention that overcomes the deeply rooted intergroup boundaries between the nonRoma majority and Roma minority in Slovakia will present a challenge (see Kočišová, 2015; Szescányiová, 2016 for the initial results). In fact, research on direct contact with members of other national groups shows that negative contact with outgroup members (although less frequent than positive contact) is comparatively more influential in shaping outgroup attitudes than positive contact, especially where the negativity is reported around the contact person rather than the contact situation (Graf, Paolini, \& Rubin, 2014). ${ }^{12}$ The frequency and quality of previous direct contact is therefore an important variable that should be taken into account when measuring the effect of interventions aimed at reducing anti-Roma prejudice in Slovakia.

\section{Measures of the $\mathrm{ABC}$ of prejudice in social psychology research}

There are numerous different instruments in international research for measuring stereotypes and prejudice. In their synthetic chapter, Fiske and North (2014) offer a historical review of measures of ethnic and racial bias in social psychology. Initially the research focused on assessing intergroup social distance (Bogardus, 1927) and the content of stereotypes (Katz \& Braly, 1933). The Authoritarian Personality scales were developed in response to the Holocaust and predicted anti-Semitism and ethnocentrism (Adorno et al., 1950). Surveys conducted from World War II until the present day have studied racial and ethnic attitudes (Kinder \& Schuman, 2004, cited in Fiske \& North, 2014). With the rise of the civil rights movement, racial attitudes became more complicated than self-reports were able to detect, so nonverbal indicators were developed (Crosby et al., 1980, cited in Fiske \& North, 2014). The existence of masked forms of prejudice inspired work on symbolic and modern

\footnotetext{
${ }^{12}$ The authors suggest that the greater prevalence of positive contact may compensate for the greater prominence of negative contact, leading to modest improvements in outgroup attitudes after intergroup contact (Graf, Paolini, \& Rubin, 2014).
} 







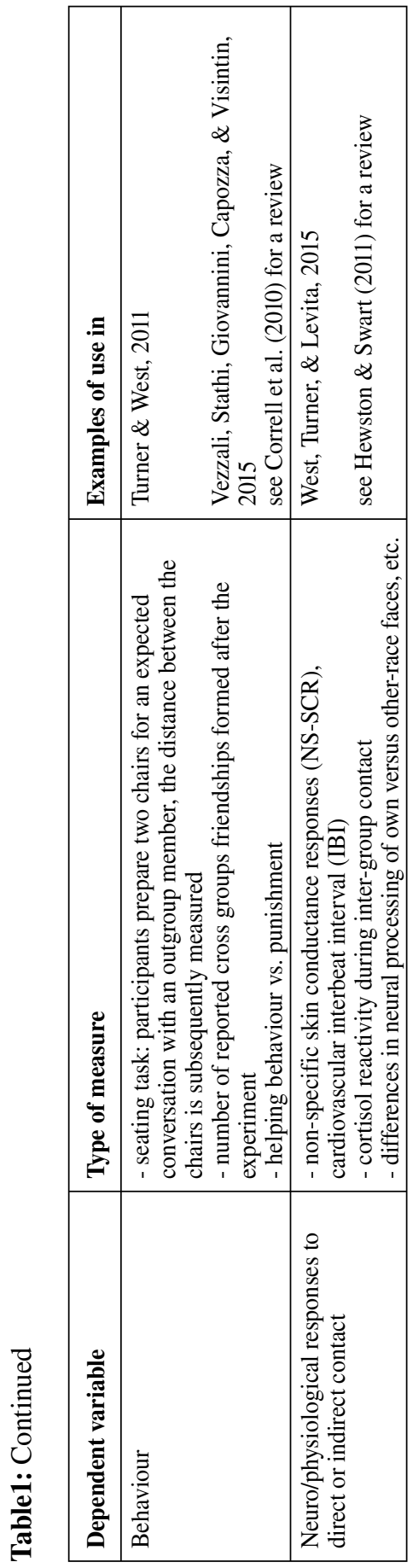

racism (McConahay, 1986; Kinder \& Sears, 1981), subtle and blatant prejudice (Pettigrew \& Meertens, 1995), and implicit prejudice (Greenwald \& Banaji, 1995).

Yet the published research that deals with measuring anti-Roma prejudice in Slovakia does not draw on the great variety of established questionnaire measures in social psychology. Instead it uses mainly attitudinal Likert scales, the Bogardus social distance scale $^{13}$ (Rosinský, 2009; Gallová Kriglerová, Kadlečíková, Alenová, Mistrík, \& Rafael, 2009 , etc.) and psycho-semantic methods, such as the semantic differential and semantic selection test (Šramová, 2010; Šramová \& Poliaková, 2010). Conversely, in the Czech Republic, in addition to social distance measures (Klicperová-Baker \& Koštál, 2012), explicit stereotypes and prejudice have been measured using the National Character Survey (Terracciano et al., 2005, cited in Hřebíčková \& Graf, 2015; Hřebíčková \& Graf, 2014), the revised NEO Personality Inventory (Hřebíčková \& Graf, 2014), the Stereotype Content Model and realistic and symbolic threat scales (Tausch et al., 2007, cited in Žingora \& Graf, 2014) as well as scales of traditional and modern racism (Hnilica \& Radová, 2013). Implicit attitudes have been measured in one Czech study, via affective priming (Hnilica \& Radová, 2013), but not in Slovakia. ${ }^{14}$

When adapting the existing measures for our purposes, we were interested in generic

\footnotetext{
${ }^{13}$ See Vašečka (2006) for a discussion on problems using the Bogardus scale to measure anti-Semitism in Slovak sociological research.

${ }^{14} \mathrm{~A}$ research project is currently being coordinated by social psychologist Dr. Anna Kende from ELTE Budapest in Hungary, which aims to construct a complex anti-Roma prejudice scale and validate it in different cultures including Slovakia. For the situation regarding Roma in Hungarian schools see Kende (2011).
} 
scales (Davis \& Engel, 2011) that could also be used to measure the effect of contact interventions in reducing prejudice against minorities other than Roma. We surveyed the existing literature on (direct and indirect) contact in order to determine which dependent variables and measures were most typically used to capture the $\mathrm{ABC}$ of prejudice. These measures are presented in Table $1 .^{15}$

As Table 1 suggests, the most typically used measures predominantly focus on A affective aspects (mainly anxiety, but also empathy) and $\mathrm{C}$ - cognitive aspects of prejudice. The B - behavioural aspects are mainly studied using behavioural intentions as a proxy. If actual behaviour is assessed, it is predominantly studied under laboratory conditions. To address this shortcoming and to partly overcome the difficulties inherent in observing behaviour under field conditions, we decided to try using the correspondence test of discrimination (Bertrand \& Mullainathan, 2004) adapted for use in schools. ${ }^{16}$

\section{Two questionnaires for measuring intergroup stereotypes and prejudice in Slovakia}

Based on an analysis of the literature, we decided to compile a comprehensive questionnaire (which we labelled INTERMIN, the acronym of the project title) that would encompass the most typical areas covered by contact paradigm research, and adapted for use in schools. We also decided to adapt the Stereotype Content Model (SCM, Fiske, Cuddy, Glick, \& Xu, 2002) for use in Slovakia, which would enable us to explore the content of stereotypes on stigmatized minorities.

\section{INTERMIN questionnaire}

The first questionnaire explores the dependent variables used most frequently in contact research, such as attitudes, social distance, intergroup anxiety, intergroup trust and behavioural intentions towards Roma. The attitudes were measured by a feeling thermometer (0-100), while the other dependent variables were measured on 7-point Likert scales. We used the Bogardus scale ${ }^{17}$ to ask about social distance between Roma and the majority population via items such as If a Rom was your classmate would that be... (scale 1

\footnotetext{
${ }^{15} \mathrm{We}$ also surveyed the established scales that deal with various facets of prejudice and stereotypes (such as the Stereotype Content Model scale, the Symbolic Racism scale, and the Subtle and Blatant Prejudice scale). As our primary goal is to measure the effect of direct and indirect interventions, we deliberately chose not to use measures that concentrate on intra-individual level explanations of prejudice, such as the Social Dominance Orientation scale (Pratto, Sidanius, Stallworth, \& Malle, 1994), the Right Wing Authoritarianism scale (Altemeyer, 1988) or the Motivation to Respond without Prejudice scale (Plant \& Devine, 1998).

${ }^{16}$ The correspondence test of discrimination measures the amount of discriminatory behaviour under field conditions. The first test was carried out in the USA, and it found that work agencies answered job applications by applicants who had a White-sounding name more frequently than those with AfricanAmerican names, in spite of their CVs being totally identical (Bertrand \& Mullainathan, 2004). Other behavioural field measures include the "lost letter" technique and variations on it (see Correll et al., 2010 for a review).

${ }^{17}$ We do not use it as a cumulative scale as it has repeatedly been proven that Bogardus does not perform this function (Correll et al., 2010).
} 
"totally unacceptable" to 7 "totally acceptable"), intergroup anxiety using items such as If a new Roma classmate came to your class, how would you feel?... (items such as "I would be worried", "It would make me nervous", "I would feel relaxed", etc." scale 1 - "does not describe my feelings at all" to 7 "totally describes my feelings"), intergroup trust using items such as Most Roma can be trusted (scale 1 "totally disagree" to 7 "totally agree") and approach and avoid behavioural intentions towards Roma using items such as How would you react if a new Roma classmate joined your class? (items such as "I would like to find out more about him/her", "I would like to avoid him/her", etc.; scale 1 - "totally disagree" to 7 - "totally agree").

We also added items measuring the frequency of direct contact ${ }^{18}$ with Roma using items such as How often do you come into contact with Roma in public (in the street, in a shop)? (scale 1 "never", 2 "less than once a month", 3 "once a month", 4 "several times a month", 5 "once a week", 6 "several times a week" to 7 "every day"); and the quality of contact using items such as In general, how do you evaluate your encounters with Roma? (scale 1 "very unpleasant" to 7 "very pleasant"). ${ }^{19}$

\section{SCM questionnaire}

Since we wanted to use a standardized measure of stereotype content, we decided to adapt the Stereotype Content Model (SCM) into Slovak. ${ }^{20}$ The SCM identifies two fundamental dimensions of (biased) social perception of various groups in society (Cuddy, Fiske, \& Glick 2007; Fiske, Cuddy, Glick, \& Xu, 2002). The first dimension, perceived warmth, reflects the group's intention for good or ill (friend/foe), and the second dimension, perceived competence, reflects the group's ability to enact that intent (capability). These then generate the two-dimensional liking (warmth) x respect (competence) space (Fiske \& North, 2014). Among the univalent combinations, the most obvious ingroups and societal reference groups (e.g., the middle class, citizens) appear high on both dimensions; whereas extreme outgroups (drug addicts, homeless people) appear low on both dimensions (Fiske \& North, 2014). Some

\footnotetext{
${ }^{18}$ Frequency and quality of contact are important moderators of the effect of contact in reducing prejudice, as shown in cross-sectional (Graf, Paolini, \& Rubin, 2014) and experimental (Hoffarth \& Hodson, 2015) studies.

${ }^{19}$ These are the items used in the first version of the questionnaire that we subsequently piloted - quantitatively and qualitatively. The revised wordings following the cognitive interviews can be found in Popper and Petrjánošová (2016, this issue).

${ }^{20}$ The Slovak version is based on translation from the English original of SCM. Although we took into consideration the Czech version (Žingora, 2014), we decided to deal with the translation of some items differently. For example, while in the Czech version the adjective "competent" is translated as "kompetentní", we decided to use the Slovak word "schopní" instead, as we found in a pilot study that the adjective "kompetentný" in Slovak language was semantically related to the administrative and organizational domain, and the participants did not understand its meaning unless a particular domain of competence was specified (e.g. a competent lawyer). We were also unable to directly use the Czech translation of the item "warm" ("vřelý" in Czech - "vrelý" in Slovak). In fact, the adjective "vrelý" in Slovak evoked in participants negative feelings related to anger and heated emotions. Hence we decided to use the adjective "srdečný" instead, which means "warm-hearted" in English.
} 
of the ambivalent combinations convey the idea of competent but cold (rich people, outsider entrepreneurs) and others warm but incompetent (older people, disabled people, Fiske \& North, 2014). These quadrants vary in the groups they contain across societies, but the two dimensions of warmth and competence are universal across a variety of cultures and settings (Fiske \& North, 2014).

The SCM is not an individual-difference measure, but a description of reported intergroup reactions at society level (Fiske \& North, 2014). SCM measures the groups' trait images (stereotypes) on the fundamental dimensions of perceived warmth (using items such as warm, good-natured, friendly, sincere, trustworthy), and perceived competence (using items such as competent, capable, confident, skilled, intelligent, Fiske \& North 2014; Fiske et al., 2002; Cuddy et al., 2007). The SCM usually uses two to four items to measure each of these dimensions, and the combinations may vary. In the first version of the Slovak questionnaire, we used four items to measure each dimension. Competence was measured with the items "competent, capable, confident, skilled" and warmth with the items "warm, good-natured, friendly, sincere". The SCM questionnaire also measures social structure related items such as status and competitiveness. We also produced Slovak versions and piloted items measuring the emotions and behaviours associated with the particular combinations of the two dimensions of stereotype content (BIAS map) as described in Cuddy et al. (2007). The main types of emotions concern feelings related to contempt, admiration, pity and envy. The main types of behaviour relate to active/passive facilitation and active/passive harm. We also added items measuring the frequency and quality of direct contact with Roma, identical to those used in the INTERMIN questionnaire.

\section{Three challenges faced when developing and adapting measures of stereotypes and prejudice for use in Slovakia}

In the process of developing and adapting the two questionnaires we had to deal with several conceptual and linguistic challenges. We faced three main problems: 1 . The influence of masculine/feminine language forms on intergroup social perception; 2. Responsible use of ethnonyms: social desirability and reproduction of stereotypes; 3. Reformulating instructions in questionnaires to measure the impact of interventions. In this paper we reflect on the choices we made as researchers when choosing and translating the original items from other languages, while the problems that the particular wording of items posed to our participants are analysed in more detail in Popper and Petrjánošová (2016, this issue). ${ }^{21}$

\section{The influence of masculine/feminine words on intergroup social perception}

The literature on intergroup contact recognizes that gender plays an intervening role in intergroup perception - men and women may react differently to same sex outgroup targets

\footnotetext{
${ }^{21}$ Based on these difficulties and the fact that our experience has tended towards qualitative research, we decided to test our questionnaires by holding qualitative individual and group cognitive interviews in order to gain a deeper insight into how particular items are understood by the general public. This is analyzed in Popper and Petrjánošová (2016, this issue).
} 
than to opposite sex output targets (see Turner, West, \& Christie, 2013). When piloting the first draft of the INTERMIN questionnaire ${ }^{22}$, we found that some participants reacted differently if the "Roma classmate" we repeatedly asked about, was female rather than male. In Slovak, unlike in English, there is no strictly gender neutral word; the ethnonyms differ according to the gender of the person (Róm - a male Rom; Rómka - a female Rom. Therefore, to avoid creating the impression we were only interested in male Roma, we had to put both forms in the questionnaire separated by a slash, e.g. Róm/Rómka (male Rom/female Rom). However, we did not know the gender of the person the participant was thinking of (male, female or non-specific) and were not able to determine whether participants would react the same to a classmate of the same gender as they would to one of the opposite gender. Therefore, we added a question in the "manipulation checks" section of the questionnaire that asked explicitly about whom the participants were thinking of when answering the questions, which partially solves the problem.

\section{Responsible use of ethnonyms: social desirability and reproduction of stereotypes}

There is an inherent tension between the social science standards on the use of ethnonyms and their use in everyday speech. In this case the problem concerns the use in Slovak of the ethnonyms Róm/Cigán (Roma/Gypsy) and their antonyms neróm/biely (non-Roma/ white). In using the politically correct term Roma we might convey to the respondents expectations about the proper way of responding to questions and thus create a social desirability bias in their responses (Fisher, 1993). Conversely, using the term Cigán (Gypsy) has negative connotations, which would contribute to the reproduction of Roma othering and stigmatization.

Using ethnonyms in data collection for scientific and administrative purposes is one of the most frequent ways of reproducing race, ethnicity and nationhood as categories of "vision and division" (Brubaker, 2002). Statistical representations of race and ethnic categories are powerful instruments for creating and maintaining putative group boundaries and asymmetrical power relationships (Simon \& Piché, 2012). In addition to this macroperspective, a micro one stresses the perpetuation of stereotypes about categories (groups) of people by using distinctively worded and phrased language (Maass, 1999) that add up to a socially shared repository of stereotypical contents (Lyons \& Kashima, 2003).

We had to account for the reproduction of stereotypical content about Roma via language in both questionnaires. For example, we deliberately chose not to use and adapt the original SCM item "intelligent" because we are convinced it refers to old-fashioned racism and we were not willing to risk reproducing these kinds of racial stereotypes through our research. Cognitive interviews about the pilot version of the questionnaire (Popper \& Petrjánošová, 2016) also revealed that the adjective "capable" (schopný) used in the SCM could have undesirable negative connotations in connection to the Roma minority (e.g. "they are capable of anything", "they are capable thieves"). Yet this adjective would probably not have the same

\footnotetext{
${ }^{22}$ The draft version of the questionnaire was created with the help of Monika Kočišová, as a part of her thesis for her Master's degree at the Faculty of Social and Economic Sciences, Comenius University in Bratislava (Kočišová, 2015).
} 
meaning if it were used to describe members of another group or social category - therefore we decided it to keep it for the sake of future comparison (for further arguments see Popper \& Petrjánošová, 2016, this issue). But when interpreting the results of the SCM and comparing the scores of the different outgroups on the dimension of competence we should be aware of possible differences in representations of particular dimensions for different outgroups.

\section{Reformulating instructions in questionnaires to measure the impact of interventions}

The SCM scale is not typically used in experiments that measure the effect of contact interventions on prejudice reduction because the original instruction explicitly asks the participants to rate outgroups from the point of view of "most people" in that society, and thus to answer in accordance with socially-shared stereotypes. This might pose problems when seeking to measure the effect of contact interventions because the instruction to answer in accordance with the view of the majority of people could potentially neutralize the effect of the interventions by shifting participants' attention away from their own views (which might change as a result of the intervention) to those of the majority (that were not exposed to the intervention). ${ }^{23}$

To our knowledge, the only study that used the SCM in indirect contact experimental research is a study by Bilewicz and Kogan (2013). They used a two-item measure of stereotype content in which participants were asked to rate (1) how competent and (2) how likeable a target group was on a Likert scale ranging from 1 (not at all) to 10 (to a great extent). However, this rating was done from the perspective of the participant not from the perspective of the majority society, as in the original version of the SCM. The reason Bilewicz and Kogan did not use the original instruction in Poland was that most Polish students do not identify with Polish society. Therefore if they had been asked what Poles thought about Roma, they would have come up with very negative statements that did not necessarily reflect their personal opinions (Bilewicz, personal communication, May 26, 2016). This problem also arose in cognitive interviews with Slovak university students as some of them explicitly refused to endorse the widely shared majority racist views that are not socially stigmatized in Slovak society. However, when the high school students were asked in the second round of cognitive interviews how they would have answered if they had been asked for their own opinion, they said they would probably have given the same answer most of the time.

In order to find out whether the phrasing of the instruction influences the responses, we decided to design a study that would test whether individual-based ("in your opinion") and society-based ("according to most people in Slovakia") instructions impact on the content of stereotypes conveyed by respondents. In addition, we intend to test whether changing the instruction to make it more socially relevant ("according to most of your classmates") could make the SCM an ecologically valid measure for prejudice-reduction interventions in schools.

\footnotetext{
${ }^{23}$ The main reason we decided to use the SCM is that it makes it possible to compare the content of stereotypes of various social categories in a particular society within one semantic space, and that it is a theory-driven measure not an ad-hoc tool.
} 


\section{Conclusion}

Developing measures of stereotypes and prejudice to be used in Slovakia was not easy and we hope that researchers in other countries, working on similar projects, will profit from our (sometimes hard-learned) lessons. We cannot stress enough that measures of stereotypes and prejudice should be designed and conducted in a responsible and sensitive manner and that in measuring various forms of social bias we do not reproduce its cognitive, emotional and behavioural manifestations.

\section{References}

Adorno, T. W., Frenkel-Brunswik, E., Levinson, D. J., \& Sanford, R. N. (1950). The authoritarian personality. New York: Harper and Row.

Allport, G. W. (1979). The nature of prejudice: 25th anniversary edition. New York: Basic Books.

Altemeyer, B. (1988). Enemies of freedom: Understanding right-wing authoritarianism. San Francisco: Jossey-Bass Publishers.

Aron, A., Aron, E. N., \& Smollan, D. (1992). Inclusion of other in the self scale and the structure of interpersonal closeness. Journal of Personality and Social Psychology, 63, 596-612.

Banaji, M. R., \& Greenwald, A. G. (2013). Blindspot: The hidden biases of good people. New York: Delacorte Press.

Batson, C. D. (1991). The altruism question: Toward a social-psychological answer. Hillsdale, NJ: Erlbaum Associates.

Bertrand, M., \& Mullainathan, S. (2004). Are Emily and Greg more employable than Lakisha and Jamal? A field experiment on labor market discrimination. American Economic Review, 94(4), 9911013.

Bilewicz, M., \& Kogan, A. (2014). Embodying imagined contact: Facial feedback moderates the intergroup consequences of mental simulation. British Journal of Social Psychology, 53, 387-395.

Birtel M. D., \& Crisp, R. J. (2015). Psychotherapy and social change: Utilizing principles of cognitivebehavioral therapy to help develop new prejudice-reduction interventions. Frontiers in Psychology, $6,1771$.

Bogardus, E. S. (1927). Race friendliness and social distance. Journal of Applied Sociology, 11, 272-287.

Brubaker, R. (2002). Ethnicity without groups. European Journal of Sociology, 43(2), 163-189.

Condor, S., \& Figgou, L. (2012). Rethinking the prejudice problematic: A collaborative cognition approach. In J. Dixon \& M. Levine, (Eds.), Beyond prejudice. Extending the social psychology of conflict, inequality and social change (pp. 200-221). Cambridge: Cambridge University Press.

Correll, J., Judd, C. M., Park, B., \& Wittenbrink, B. (2010). Measuring prejudice, stereotypes and discrimination. In J.F. Dovidio, M. Hewstone, P. Glick, \& V. M. Esses (Eds.), The SAGE handbook of prejudice, stereotyping and discrimination (pp. 45-62). London: SAGE.

Cuddy, A. J. C., Fiske, S. T., \& Glick, P. (2007). The BIAS Map: Behaviors from Intergroup Affect and Stereotypes. Journal of Personality and Social Psychology, 92, 631-648.

Davis, L. E., \& Engel, R. J. (2011). Measuring Race and Ethnicity. New York: Springer.

Dixon, J., Durrheim, K., Tredoux, C. G., Tropp, L. R., Clack, B., Eaton, L., \& Quayle, M. (2010). Challenging the stubborn core of opposition to equality: Racial contact and policy attitudes. Political Psychology, 31, 831-855.

Dixon, J., Durrheim, K., Thomae, M., Tredoux, C., Kerr, P., \& Quayle, M. (2015). Divide and rule, unite and resist: Contact, collective action and policy attitudes among historically disadvantaged groups. Journal of Social Issues, 3, 576-596.

Dixon, J., \& Levine (Eds.). (2012a). Beyond prejudice. Extending the social psychology of conflict, inequality and social change. Cambridge: Cambridge University Press. 
Dixon, J., \& Levine (2012b). Introduction. In J. Dixon, \& M. Levine (Eds.), Beyond prejudice. Extending the social psychology of conflict, inequality and social change (pp. 1-23). Cambridge: Cambridge University Press.

Dovidio, J., \& Gaertner, S. L. (2004). Aversive racism. In M. P. Zanna (Ed.), Advances in Experimental Social Psychology (Vol. 36, pp. 1-52). San Diego, CA: Academic Press.

Drál', P., \& Findor, A. (2016). Teachers as researchers? Assessing impact of pedagogical interventions on pupils' attitudes, Human Affairs, 26(3), 271-287.

Durrheim, K. (2012). Implicit prejudice in mind and interaction. In J. Dixon \& M. Levine (Eds.), Beyond prejudice. Extending the social psychology of conflict, inequality and social change (pp. 179-199). Cambridge: Cambridge University Press.

Durrheim, K., Mtose, X., \& Brown, L. (2011). Race trouble: Race, identity and inequality in postapartheid South Africa. Lanham: Lexington books.

European Commission (2015). Special Eurobarometer. Discrimination in the EU in 2015. Retrieved from http://dx.doi.org/10.2838/325154

Fisher, R. J. (1993). Social desirability bias and the validity of indirect questioning. Journal of Consumer Research, 20(2), 303-315.

Fiske, S. T., \& North, M. S. (2014). Measures of stereotyping and prejudice: Barometers of bias. In G. J. Boyle, D. H. Saklofske, \& G. Matthews (Eds.), Measures of personality and social psychological constructs (pp. 684-716). London: Academic Press.

Fiske, S. T., Cuddy, A. J., Glick, P., \& Xu, J. (2002). A model of (often mixed) stereotype content: Competence and warmth respectively follow from perceived status and competition. Journal of Personality and Social Psychology, 82, 878-902.

Fiske S.T., \& Taylor, S.E. (1984). Social cognition. Reading, MA: Addison-Wesley.

Gaertner, S. L., \& Dovidio, J. F. (2011). Conclusion: Positive thoughts about positive approaches to intergroup relations. In L. R. Tropp \& R. K. Mallett (Eds.), Moving beyond prejudice reduction: Pathways to positive intergroup relations (pp. 241-259). Washington, DC: APA.

Gallová Kriglerová, E., Kadlečíková, J., Alenová, Z., Mistrík, E., \& Rafael, V. (2009). Kultúrna rozmanitost a jej vnímanie žiakmi základných škôl na Slovensku [Cultural heterogeneity and how it is perceived by elementary school pupils in Slovakia]. Bratislava: Open Society Foundation.

Gierzynski, A., \& Eddy, K. (2013). Harry Potter and the millennials: Research methods and the politics of the muggle generation. Baltimore: The Johns Hopkins University Press.

Graf, S., Paolini, S., \& Rubin, M. (2014). Negative intergroup contact is more influential, but positive intergroup contact is more common: Assessing contact prominence and contact prevalence in five Central European countries. European Journal of Social Psychology, 44, 536-547.

Greenwald, A.G., \& Banaji, M. R. (1995). Implicit social cognition: Attitudes, self-esteem, and stereotypes. Psychological Review, 102, 4-27.

Greenwald, A. G., McGhee, D. E., \& Schwartz, J. L. K. (1998). Measuring individual differences in implicit cognition: The implicit association test. Journal of Personality and Social Psychology, 74(6), 1464-1480.

Halperin, E., Crisp, R.J., Husnu, S., Trzesniewski, K.H., Dweck, C.S., \& Gross, J.J. (2012). Promoting intergroup contact by changing beliefs: Group malleability, intergroup anxiety, and contact motivation. Emotion, 12(6), 1192-1195.

Hewstone, M., \& Swart, H. (2011). Fifty-odd years of inter-group contact: From hypothesis to integrated theory. British Journal of Social Psychology, 50(3), 374-386.

Hnilica, K., \& Radová, L. (2013). Rasismus? Postoje? Ideologie? K determinantám etnických stereotypů [Racism? Attitudes? Ideology? The determinants of ethnic stereotypes]. Československá psychologie, 57(2), 144-161.

Hodson, G., \& Dhont, K. (2015). The person-based nature of prejudice: Individual difference predictors of intergroup negativity. European Review of Social Psychology, 26, 1-42. 
Hoffarth, M. R., \& Hodson, G. (2015). Who Needs Imagined Contact? Replication Attempts Examining Previous Contact as a Potential Moderator. Social Psychology 47, 118-124.

Hřebíčková, M., \& Graf, S. (2014). Accuracy of national stereotypes in central Europe: Outgroups are not better than ingroup in considering personality traits of real people. European Journal of Personality, 28, 60-72.

Hřebíčková, M., \& Graf, S. (2015). How we see the ingroup sometimes reflects how we see the outgroups: mirroring of national stereotypes in Central Europe. Československá psychologie, 59, 91-99.

Katz, D., \& Braly, K. (1933). Racial stereotypes of one hundred college students. Journal of Abnormal and Social Psychology, 28(3), 280-290.

Kende, A. (2011). Admission policy and social inequalities in primary education in Hungary. In S. M. Degirmencioglu (Eds.), Some still more equal than others? Or equal opportunities for all? (pp. 5365). Strasbourg: Council of Europe.

Kinder, D. R., \& Sears, D. O. (1981). Prejudice and politics: symbolic racism versus racial threats to the good life. Journal of Personality and Social Psychology, 40, 414-431.

Klicperová-Baker, M., \& Koštál, J. (2012). Diverzita či odlišné chování? Sociální distance od Romů, gayů, lidí s AIDS a dalších menšin [Diversity or behavioural deviance? Social distance and Roma, gays, people with AIDS and other minorities]. Československá psychologie, 56, 297-314.

Kočišová, M. (2015). Predstavovaný kontakt ako nástroj zmierňovania predsudkov voči minoritám (diplomová práca) [Imagined contact as a tool for reducing prejudice against minorities. Unpublished M. A. Thesis]. Bratislava: FSEV UK.

Kteily, N., Bruneau, E., Waytz, A., \& Cotterill, S. (2015). The ascent of man: Theoretical and empirical evidence for blatant dehumanization. Journal of Personality and Social Psychology, 109(5), 901931.

Kuchenbrandt, D., Eyssel, F., \& Seidel, S. K. (2013). Cooperation makes it happen: Imagined intergroup cooperation enhances the positive effects of imagined contact. Group Processes Intergroup Relations, 16(5), 635-647.

Lyons, A., \& Kashima, Y. (2003). How are stereotypes maintained through communication? The influence of stereotype sharedness. Journal of Personality and Social Psychology, 85(6), 989-1005.

Maass, A. (1999). Linguistic intergroup bias: stereotype perpetuation through language. In Advances in experimental social psychology (Vol. 31, pp. 79-121). New York: Academic Press.

Machlica, G., Žúdel, B., \& Hidas, S. (2014). Bez práce nie sú koláče [No pain, no gain]. Retrieved from http://www.finance.gov.sk/Components/CategoryDocuments/s_LoadDocument.aspx?Category Id $=9887 \&$ documentId $=12632$

McConahay, J. B. (1986): Modern racism, ambivalence, and the modern racism scale. In J. F. Dovidio \& S. L. Gaertner (Eds.), Prejudice, discrimination, and racism (pp. 91-125). Orlando: Academic Press.

Miles, E., \& Crisp, R. (2014). A meta-analytic test of the imagined contact. Group Processes Intergroup Relations, 17(3), 3-26.

Mušinka, A., Škobla, D., Hurrle, J., Matlovičová, K., \& Kling, J. (2014). ATLAS rómskych komunít na Slovensku 2013 [Atlas of Roma communities in Slovakia 2013]. Bratislava: UNDP.

Paluck, E. L., Shepherd, H., \& Aronow, P. M. (2016). Changing climates of conflict: A social network experiment in 56 schools. Proceedings of the National Academy of Sciences, 113(3), 56-571.

Pettigrew, T. F., \& Meertens, R.W. (1995). Subtle and blatant prejudice in western Europe. European Review of Social Psychology, 25, 57-75.

Pettigrew, T. F., \& Tropp, L. R. (2006). A meta-analytic test of intergroup contact theory. Journal of Personality and Social Psychology, 90, 751-83.

Pittinsky, T.L., Rosenthal, S.A., \& Montoya, M.R. (2011). Measuring positive attitudes toward outgroups: Development and validation of the allophilia scale. In L.R. Tropp \& R. K. Mallett (Eds.), Moving beyond prejudice reduction: Pathways to positive intergroup relations (pp. 41-60). Washington, DC: APA. 
Plant, E. A., \& Devine, P. G. (1998). Internal and external motivation to respond without prejudice. Journal of Personality and Social Psychology, 75, 811-832.

Plichtová, J., \& Paholíková, V. (2014). Anti-rómsky bilbord : analýza obrazu a médií [Anti-Roma billboard: analysis of the image and the media]. Ceskoslovenská psychologie, 58, 387-401.

Popper, M., \& Petrjánošová, M. (2016). Do we know what we are asking? Cognitive interviews and discussions. Human Affairs, 26(3), 253-270.

Popper, M., Szeghy, P., Poduška, O., \& Kollárik, R. (2011). Iná realita: chudoba, sociálna deprivácia a uživanie inhalantov $v$ rómskych osídleniach na východnom Slovensku [A different reality: Poverty, social deprivation and the use of inhalants in Roma settlements in eastern Slovakia]. Bratislava: Open Society Foundation.

Popper, M., Szeghy, P., \& Šarkozy, Š. (2009). Rómska populácia a zdravie: Analýza situácie na Slovensku [Roma population and health: An analysis of the situation in Slovakia]. Bratislava: Partners for Democratic Change Slovakia.

Pratto, F., Sidanius, J., Stallworth, L. M., \& Malle, B. F. (1994). Social dominance orientation: A personality variable predicting social and political attitudes. Journal of Personality and Social Psychology, 67(4), 741-763.

Reicher, S. (2012). From perception to mobilization: The shifting paradigm of prejudice. In J. Dixon, $\&$ M. Levine (Eds.), Beyond prejudice. Extending the social psychology of conflict, inequality and social change (pp. 27-47). Cambridge: Cambridge University Press.

Rosinský, R. (2009). Etnické postoje učitelov, študentov a žiakov I. stupña ZŠ (s akcentom na rómsku etnickú skupinu) [Ethnic attitudes of teachers, students and pupils in the first four years of primary school (focusing on the Roma ethnic group)]. Nitra: Univerzita Konštanína Filozofa v Nitre, Fakulta sociálnych vied a zdravotníctva.

Rusnáková, J., \& Rochovská, A. (2014). Segregácia obyvatelov marginalizovaných rómskych komunít, chudoba a znevýhodnenia súvisiace s priestorovým vylúčením. [Segregation of inhabitants in marginalized Roma communities, poverty and disadvantages related to spatial segregation]. Geographia Cassoviensis, 8, 162-172.

Simon, P., \& Piché, V. (2012). Accounting for ethnic and racial diversity: The challenge of enumeration. Ethnic and Racial Studies, 35(8), 1357-1365.

Stathi, S., \& Crisp, R. J. (2008). Imagining intergroup contact promotes projection to outgroups. Journal of Experimental Social Psychology, 44(4), 943-957.

Stathi, S., Crisp, R. J. (2010). Intergroup contact and the projection of positivity. International Journal of Intercultural Relations, 34, 580-591.

Stathi S., Tsantila, K., \& Crisp R. J. (2012). Imagining intergroup contact can combat mental health stigma by reducing anxiety, avoidance and negative stereotyping. Journal of Social Psychology, 152, 746-757.

Stephan, W. G., \& Stephan, C. W. (1985). Intergroup anxiety. Journal of Social Issues, 41, 157-175.

Szecsányiová, K. (2016). Úloha kooperácie pri zmierňovaní predsudkov voči stugmatizovaným minoritám: overovanie intervencií prostredníctvom predstavovaného kontaktu. Diplomová práca. [The role of cooperation in reducing prejudice against stigmatized minorities: testing imagined contact interventions. Unpublished M. A. thesis]. Bratislava: FSEV UK.

Šramová, B. (2010). Diskriminácia na trhu práce - psychologický pohlad [Discrimination on the labour market - a psychological perspective]. In B. Šramová (Ed.), Tolerancia a intolerancia v spoločnosti (pp. 17-35). Bratislava: Melius.

Šramová, B., \& Poliaková, E. (2010). Multikulturálna edukácia v školách [Multicultural education in schools]. In B. Šramová (Ed.), Tolerancia a intolerancia v spoločnosti (pp. 55-66). Bratislava: Melius.

Štatistický úrad SR (2011). Sčítanie obyvatelov domov a bytov [Census 2011]. Retrieved from http:// census2011.statistics.sk/

Štátna školská inšpekcia (2016a). Správa o stave a úrovni výchovy a vzdelávania k ludským právam v základnej škole v školskom roku 2015/2016 v SR. [Report on the state of human rights education 
in primary school during the 2015/16 school year in the Slovak Republic]. Accessed on May 26, 2016 from https://www.ssiba.sk/ Default.aspx?text=g\&id=3\&lang=sk

Štátna školská inšpekcia (2016b). Správa o stave a úrovni výchovy a vzdelávania k ludským právam v strednej škole v školskom roku 2015/2016 v SR [Report on the state of human rights education in secondary school during the 2015/16 school year in the Slovak Republic]. Accessed on May 26, 2016 from https://www.ssiba.sk/ Default.aspx?text=g\&id=3\&lang=sk

Tam, T., Hestone, M., Kenworthy, J., \& Cairns, E. (2009). Intergroup trust in Northern Ireland. Personality and Social Psychology Bulletin, 35(1), 45-59.

Tropp, L., R., \& Mallett, R. K. (Eds.). (2011a). Moving beyond prejudice reduction: Pathways to positive intergroup relations. Washington, DC: APA.

Tropp, L., R., \& Mallett, R. K. (Eds.). (2011b). Introduction: Charting new pathways to positive intergroup relations. In L.R. Tropp, \& R. K. Mallett (Eds.), Moving beyond prejudice reduction: Pathways to positive intergroup relations (pp. 3-17). Washington, DC: APA.

Turner, R. N., Crisp, R. J., \& Lambert, E. (2007). Imagining intergroup contact can improve intergroup attitudes. Group Processes and Intergroup Relations, 10, 427-441.

Turner, R. N., Hewstone, M., \& Voci, A. (2007). Reducing explicit and implicit outgroup prejudice via direct and extended contact: The mediating role of self-disclosure and intergroup anxiety. Journal of Personality and Social Psychology, 93, 369-88.

Turner, R.N., \& Crisp, R.J. (2010). Imagining intergroup contact reduces implicit prejudice. British Journal of Social Psychology, 49, 129-142.

Turner, R. N., \& West, K. (2011). Behavioural consequences of imagining intergroup contact with stigmatized outgroups. Group Processes \& Intergroup Relations, 15, 193-202.

Turner, R. N., West, K., \& Christie, Z. (2013). Outgroup trust, intergroup anxiety, and outgroup attitude as mediators of the effect of imagined intergroup contact on intergroup behavioural tendencies. Journal of Applied Social Psychology, 43, 196-205.

Vašečka, M. (2001). Vztah majoritnej populácie k Rómom [Relations between the majority population and the Roma]. In O. Gyarfášová, V. Krivý, \& M. Velšic (Eds.), Krajina v pohybe. Správa o politických názoroch a hodnotách ludí na Slovensku. Bratislava: IVO 2001.

Vašečka, M. (2002). Vztah majority k Rómom [Relations between the majority and the Roma]. In M. Vašečka (Ed.), Čačipen pal o Roma. Súhrnná správa o Rómoch na Slovensku (pp. 335-351). Bratislava: IVO.

Vašečka, M. (2006). Sociologický výskum antisemitizmu na Slovensku po roku 1989 v kritickej perspektíve [A critical perspective on sociological research into anti-semitism in Slovakia after 1989]. Sociológia, 38, 283-312.

Vezzali, L. Stathi, S., \& Giovannini, D. (2012). Indirect contact through book reading: Improving adolescents' attitudes and behavioural intentions towards immigrants. Psychology in the Schools, 49, 148-162.

Vezzali, L., Capozza, D. Stathi, S., \& Giovannini, D. (2012). Increasing outgroup trust, reducing infrahumanization, and enhancing future contact intentions via imagined intergroup contact. Journal of Experimental Social Psychology, 48, 437-440.

Vezzali, L., Stathi, S., Crisp, R.J. \& Capozza, D. (2015). Comparing direct and imagined intergroup contact among children: Effects on outgroup stereotypes and helping intentions. International Journal of Intercultural Relations, 49, 46-53.

Vezzali, L., Stathi, S., Crisp, R. J., Giovannini, D., Capozza, D., \& Gaertner, S. L. (2015). Imagined intergroup contact and common ingroup identity: An integrative approach. Social Psychology, 46(5), 265-276.

Vezzali, L., Stathi, S., Giovannini, D. Capozza, D., \& Trifiletti, E. (2015). The greatest magic of Harry Potter: Reducing prejudice. Journal of Applied Social Psychology, 45, 105-121. 
Vezzali, L., Stathi, S., Giovannini, D., Capozza, D., \& Visintin, E. P. (2015). 'And the best essay is...': Extended contact and cross-group friendships at school. British Journal of Social Psychology, 54, 601-615.

West, K., Husnu, S., \& Lipps, G. (2015). Imagined contact works in high-prejudice contexts: Investigating imagined contact's effects on anti-gay prejudice in Cyprus and Jamaica. Sexuality Research and Social Policy, 12, 60-69.

West, K, Turner, R., \& Levita, L. (2015). Applying imagined contact to improve physiological responses in anticipation of intergroup interactions and the perceived quality of these interactions. Journal of Applied Social Psychology, 45(8), pp. 425-436.

Wetherell, M., \& Potter, J. (1992). Mapping the language of racism: Discourse and the legitimation of exploitation. London and New York: Harvester Wheatsheaf and Columbia University Press.

Wright, S. C., Aron, A., McLaughlin-Volpe, T., \& Ropp, S. A. (1997). The extended contact effect: Knowledge of cross-group friendships and prejudice. Journal of Personality and Social Psychology, 73, 73-90.

Zagefka, H., González, R., Brown, R., Lay, S., Manzi, J., \& Didier, N. (2015). To know you is to love you: Effects of intergroup contact and knowledge on intergroup anxiety and prejudice among indigenous Chileans. International Journal of Psychology, DOI: 10.1002/ijop.12229

Zanna, M.P., \& Rempel, J.K. (1988). Attitudes: A new look at an old concept. In D. Bar-Tal and A. W. Kruglanski (Ed.), The social psychology of knowledge (pp. 315-334). Cambridge, UK: Cambridge University Press.

Žeželj, I., Jakšić, I., \& Jošić, S. (2015). How contact shapes implicit and explicit preferences: attitudes toward Roma children in inclusive and non inclusive environment. Journal of Applied Social Psychology, 45(5), 263-273.

Žingora, T., \& Graf, S. (2014). Rómovia a Vietnamci z českej perspektívy. Rola hrozby vo vztahu medziskupinového kontaktu a postojov [The Roma and Vietnamese from a Czech perspective. The role played by threat in relation to intergroup contact and attitudes]. In M. Bozogáňová, M. Kopaničáková, \& J. Výrost (Eds.), Sociálne procesy a osobnost 2014 (pp. 472-480). Košice: Spoločenskovedný ústav SAV.

Žingora, T. (2014). Rómovia a Vietnamci očami väčšinovej spoločnosti: Úloha hrozby vo vzíahu medziskupinového kontaktu a postojov [Roma and Vietnamese as seen by the majority: The role played by threat in relation to intergroup contact and attitudes]. Diplomová práca [Unpublished M. A. Thesis]. Brno: FSS Masarykova univerzita.

Institute for Research in Social Communication,

Slovak Academy of Sciences,

Dúbravská cesta 4

84104 Bratislava

Slovakia

E-mail: barbara.lasticova@savba.sk

Institute of European Studies and International Relations,

Faculty of Social and Economic Sciences,

Comenius University in Bratislava

Mlynské luhy 4

82105 Bratislava

Slovakia

E-mail: andrej.findor@fses.uniba.sk 